\title{
Once the Earth Stood Still (Part I): Cuban Rehabilitation Services in Haiti
}

\section{By Conner Gorry, MA in Port-au-Prince}

There are dates that weigh heavy. January 12, 2010 is one of them-not only for Haitian survivors, over one million of whom are still internally displaced, but also for the 331 Cuban health professionals who were working in the Haitian public health system when the earthquake struck. Among the first responders, these doctors, nurses, and technicians serve in Cuban health cooperation programs, which have been providing care to Haitians since 1998.[1] Once the earth settled that fateful Tuesday, they were faced with an entirely new landscape, strewn with patients in urgent need of medical care.

Soon coming to their assistance were specialists from Cuba's Henry Reeve Emergency Medical Contingent: within 24 hours, they were on the ground equipped with medicine, materials, and expertise. Many of the arriving doctors, specially-trained in disaster medicine and epidemic prevention, were veterans of disasters in Pakistan, Indonesia, Central America and elsewhere. They relieved those who had been working around the clock since the quake, setting bones, cleaning wounds, treating burns, and shrouding the dead.

The magnitude of the disaster prompted successive scaling up of specialized personnel. By the first week in February, the Henry Reeve Contingent had 681 members in Haiti, incorporating some of the personnel already on the ground. A month later, that number had swelled to over 1500 and included doctors from over two dozen countries (including Haiti), graduates of Havana's Latin American Medical School (ELAM).[2] This was the tenth postdisaster mission for the Henry Reeve Contingent,[3] and experience had taught them the importance of mounting a targeted, contextually-appropriate response. In Haiti, this meant calibrating the right combination of surgeons, orthopedists, dermatologists, epidemiologists, psychologists, nurses, and obstetricians.

\section{Beyond the Emergency Phase}

Throughout the first months, Cuban-led teams treated victims alongside health professionals from the United States, Germany, New Zealand, Latin America and elsewhere. But once the emergency phase began to officially wind down in mid-March,[4] global attention shifted away from Haiti and most international medical relief teams began filtering out of the country.

Cuba too began adapting its approach, but in a different direction-by folding its emergency medical response into its long-term cooperation with Haiti. This transition is based on staffing Haiti's public health facilities over time, including 20 new community hospitals established through an agreement with the region's 8-nation Bolivarian Alliance for the Americas (ALBA, its Spanish acronym). These hospitals, now operating throughout the country, from Port Salut to Bassin Bleu and places in between, provide comprehensive services at no charge to patients. Such multilateral cooperation in health has foreshadowed other accords designed to strengthen the Haitian public health system, including a trilateral agreement among Haiti, Cuba, and Brazil signed on March 27.[5]
Cuba's Health Cooperation in Haiti, Post-Quake through April 13

\begin{tabular}{|c|c|}
\hline \multicolumn{2}{|l|}{ Infrastructure \& Staffing } \\
\hline Members in Haiti & 1491 \\
\hline $\begin{array}{l}\text { Of those, ELAM-trained } \\
\text { members }\end{array}$ & 730 \\
\hline $\begin{array}{l}\text { Countries represented } \\
\text { in contingent }\end{array}$ & $\begin{array}{l}28 \text { (Argentina, Belize, Bolivia, Brazil, } \\
\text { Chile, Colombia, Costa Rica, Cuba, } \\
\text { Dominica, Dominican Republic, Ecuador, } \\
\text { El Salvador, Guatemala, Haiti, Honduras, } \\
\text { Lebanon, Mali, Mexico, Nicaragua, } \\
\text { Nigeria, Panama, Paraguay, Peru, } \\
\text { Saharawi Arab Democratic Republic, } \\
\text { Santa Lucia, United States, Uruguay, } \\
\text { Venezuela) }\end{array}$ \\
\hline $\begin{array}{l}\text { Hospitals in quake-affected } \\
\text { areas staffed by Henry } \\
\text { Reeve members }\end{array}$ & 10 (5 are Cuban field hospitals) \\
\hline $\begin{array}{l}\text { Health posts in tent cities, } \\
\text { Port-au-Prince }\end{array}$ & 4 \\
\hline \multicolumn{2}{|l|}{ Results } \\
\hline Doctor-patient visits & 299,324 \\
\hline Surgeries & $\begin{array}{l}7899 \text { (major surgeries: 3562; } \\
\text { minor surgeries: } 4337 \text { ) }\end{array}$ \\
\hline Births attended & 1523 \\
\hline $\begin{array}{l}\text { Most common conditions } \\
\text { treated currently }\end{array}$ & $\begin{array}{l}\text { Infectious diseases and parasites } \\
\text { ( } 50 \% \text { of patients) }\end{array}$ \\
\hline People vaccinated & $\begin{array}{l}107,094 \text { (diphtheria, pertussis, tetanus, } \\
\text { measles, and mumps) }\end{array}$ \\
\hline $\begin{array}{l}\text { Patients in rehabilitation } \\
\text { services }\end{array}$ & 59,578 in 20 clinics throughout Haiti \\
\hline $\begin{array}{l}\text { Children and teens } \\
\text { participating in activities } \\
\text { to mitigate psycho-social } \\
\text { effects of quake }\end{array}$ & $\begin{array}{l}\text { 109,355 in } 437 \text { activities held throughout } \\
\text { Haiti }\end{array}$ \\
\hline
\end{tabular}

Source: Brigada Médica Cubana en Haití. Boletín de prensa No. 9. 13 Abril 2010; Port-au-Prince, Haití.

Members of the Henry Reeve Contingent have been given the opportunity to extend their service in Haiti beyond the emergency phase. Cuban members can transfer into the Comprehensive Health Program, agreeing to the standard two years of service required. In addition, the more than 700 ELAM doctors in the Contingent can choose to remain 3, 6, 12 or 24 months.[6] Despite difficult living and working conditions, the majority of health professionals living in the contingent's main Port-au-Prince tent camp have opted to stay a year or longer.

The composition of the Cuban-led team also began to evolve. More epidemiologists began to arrive, along with ultrasound technicians, psychologists, and physical therapists. Most of these health professionals, plus those volunteering to stay beyond the emergency phase, are being gradually dispatched to hospitals, health posts, and community rehabilitation clinics throughout the country. Teams of primary care doctors, nurses, and physical therapists, meanwhile, are being maintained in Port-au-Prince at Cuban-staffed hospitals, health clinics, and vaccination posts established in and around the capital's tent cities.

Perhaps more than any other natural disasters, earthquakes create a large-scale, sustained need for physical rehabilitation. In 
response, Cuba opened its first rehabilitation service on February 1 at its field hospital in Léogâne, one of the hardest hit areas. Now expanding across the country, the patient rehabilitation program exemplifies Cuba's long-term health cooperation in Haiti.

\section{Reyabilitasyon: A New Concept}

With a public health system that requires patients to purchase everything from gauze and gloves to syringes and anesthesia before a doctor will treat them, most Haitians have no choice but to withstand chronic or acute pain. Cuban rehabilitation services (reyabilitasyon in Creole) are helping to change that.

"Rehabilitation is a new service for the vast majority of Haitians. The clinics we've established after the earthquake offer treatments most have not had access to before," Dr Walter del Río, coordinator of Cuba's rehabilitation program in Haiti told me. These include: therapeutic electrical current, ultrasound and laser treatments, plus massage and various complementary and alternative modalities. Specific exercises for paralytic, chronic, and other conditions are also prescribed and practiced with their patients.

"The day we initiated services, we had two patients," physical medicine and rehabilitation specialist Dr Alexis Verdecia said. "But people took to the idea fast; once word got around that our services were free, we were flooded," he continued. Accompanying his five-member team to their workplace-an olive green tent pitched in the Centre Hospitalier de la Renaissance parking lot, overlooking the crumbling cathedral-I saw what he meant. By 7:30 am, an orderly, densely-packed line of patients had formed and would continue to grow with the length and strength of the sun's rays. During their 8 am-to- 4 pm shift, these therapists treat between 80 and 100 patients each day. By the end of March, more than 56,000 Haitians had received post-quake rehabilitation services in the 20 Cuban-staffed clinics around the country.[7]

For Cuban physical therapists here in Port-au-Prince, days begin early. The roosters start crowing by 5:00 am and the heat begins its suffocating descent not long after. Doctors in neighboring tents make early morning motions and before long, the entire camp is up. For the physical therapists, this means an early breakfast and departure for another tent-bigger, but just as hot as where they sleep each night-where they go to work.

The pace is intense: one specialist administers electrical stimulation therapy to one patient, ultrasound to another, while his colleague dons protective glasses to perform laser therapy on a third. From here, patients proceed to the farthest reaches of the tent where another pair of specialists offer therapeutic massage and help with rehabilitative exercises. Each individual receives a minimum of 20 minutes of treatment, with more complicated cases receiving up to 45 minutes. The results are encouraging: the therapists tell me of amputations averted, recovered mobility, and patients who entered in wheelchairs and have since progressed to crutches and canes. Now walking on his own again after earthquake injuries had him on crutches, one young man hugs each Cuban therapist in turn.

Due to the scarcity of resources and significant language barrier, designing and describing rehabilitation exercises can be challenging. "We have to be creative," says physical therapist Jorge Luis Cruz. "This woman for instance suffers from partial facial paralysis. Normally we'd have her blow up a balloon in front of a mirror, which helps her brain 'remember' simple facial movements. But we have no balloons, so we use surgical gloves instead. And that mirror is the biggest one I've seen in Haiti," he continued, pointing to the rectangle that ideally would be fulllength for patients to observe their posture as they perform their exercises.

This creativity repeats itself with an elderly gentleman who is regaining movement in his left hand, helped along by simple exercises like placing his fedora on his head, buttoning his shirt, and taking off his glasses before inserting them into his breast pocket. Miarelle Exantus, a young woman struggling to move a

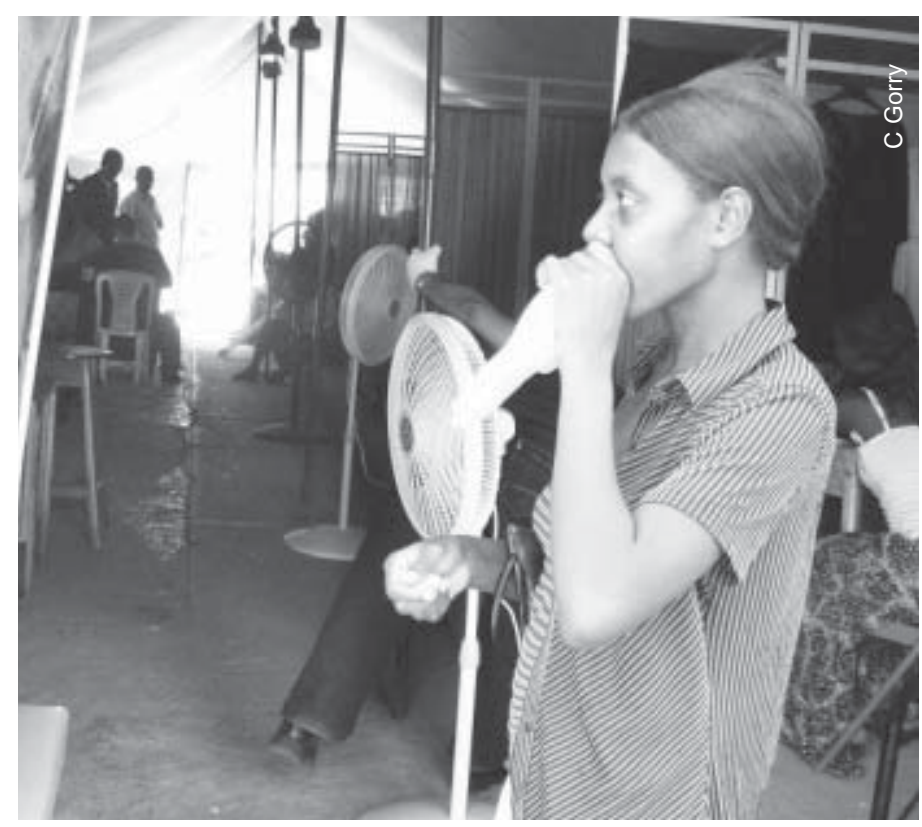

Post-quake improvisation at work: a glove substitutes a balloon for rehabilitation exercises. 
series of gradually smaller bottle tops from one side of the table to another with a hand crushed in the earthquake, has a longer, harder job ahead. "It's her right hand that's of bigger concern right now. The clinical indication is amputation, but we're working with her to do everything possible to avoid that," physical therapist Elicerio Rodríguez explained. Watching Miarelle withstand the lengthy, obviously painful rehabilitative exercises, it's clear this young woman is as determined as her therapist. While most patients see results after 10 to 15 sessions, Miarelle will require many more.

\section{From Amputatees to Arthritis Sufferers}

The Cuban health posts established after the earthquake in several of Port-au-Prince's biggest tent cities also offer rehabilitation services that have a steady stream of patients. One of these is in the Kafou Fey (Carrefour Feuilles) section of the city-an area that combines poverty, overcrowding and the occasional flash of violence. And that was prior to January 12 . Now, it is a sprawling chain of large tent cities dotted with houses that withstood the quake and rubble of those that didn't. This is where María Belkis Hernández, a physical therapist from Havana, comes to work every day.

The tent is cramped and hot, made more so by the team of doctors, nurses, and translators $\left(5^{\text {th }}\right.$-year Haitian medical students trained at the ELAM), plus the crush of patients crowded at the entrance. Belkis, as she is known, is squeezed into a narrow area on the far side of the tent where she sets up her equipment beside the simple massage table that serves as her rehabilitation station.

"At first it was a challenge since the concept of rehabilitationsomething you have to do regularly, over time-wasn't well understood," she says as she arranges her sage sticks, natural remedies that combine heat and analgesic properties to alleviate minor aches and pains. "Now I have patients who don't miss a treatment; they come every day."

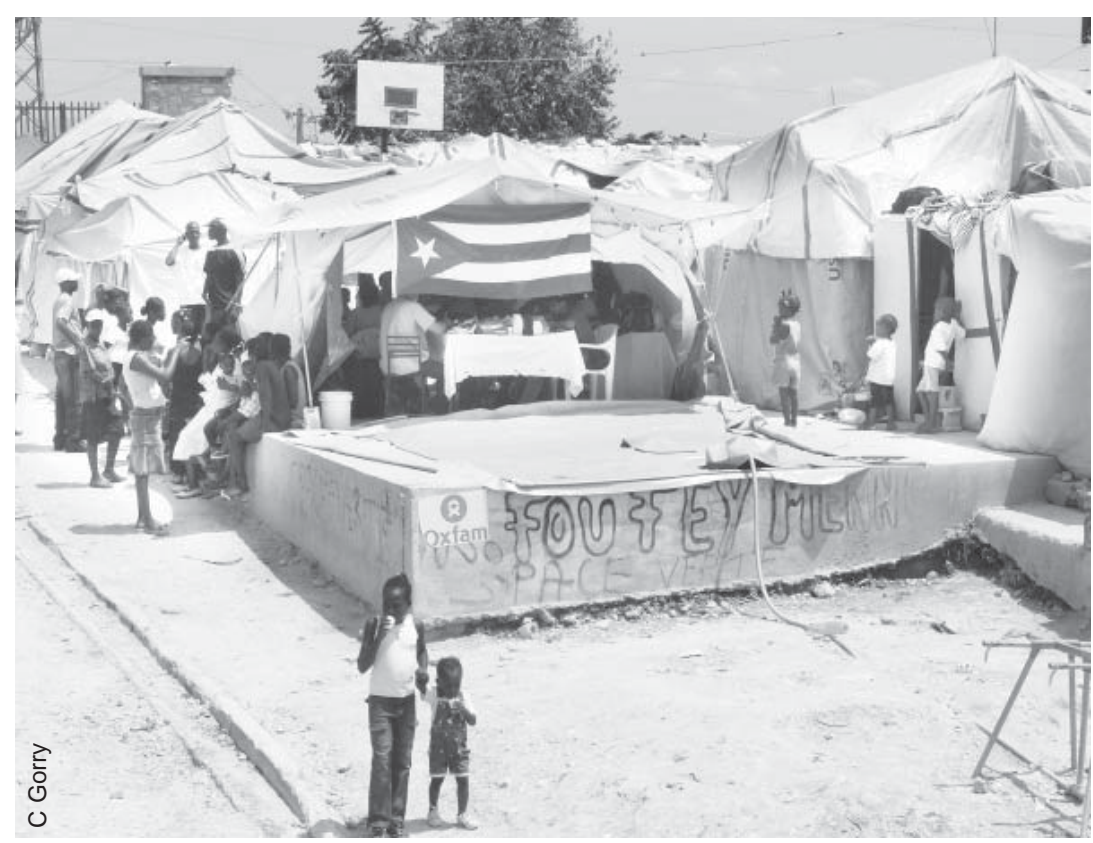

The health post in Kafou Fey staffed by Cuban, Haitian, and Latin American health professionals.

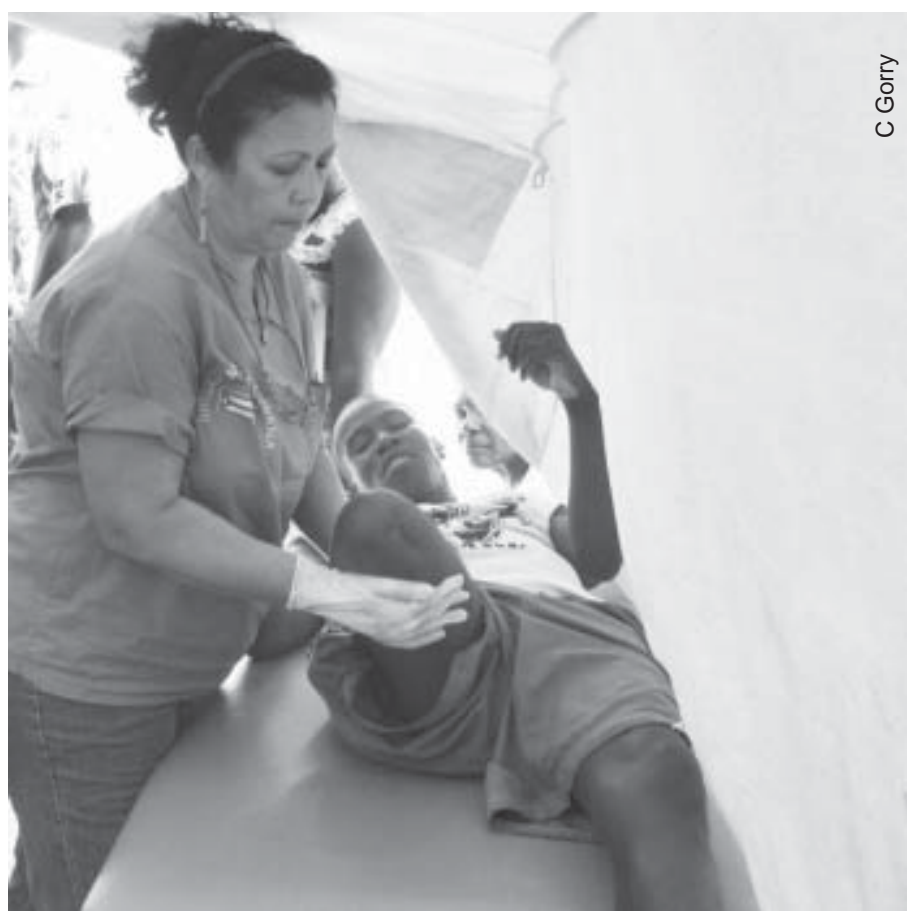

María Belkis Hernández at the Kafou Fey health post: 'I have patients who don't miss a treatment: they come every day'.

These patients run the gamut from older women suffering from arthritis, to young girls recovering from car accidents. Of course amputees-below and above the knee, above the elbow, at the wrist-are also among those visiting this and other Cuban health posts. Preparing these patients to be fitted with prostheses supplied by Cuba, the Pan American Health Organization, and other international partners, is part of the daily work now. "You have to prepare the patient physically_strengthening their torso and the stump-but their balance also has to be strengthened, in some cases entirely regained," said Belkis. Making sure the wound is completely healed and the stump is as smooth and tapered as possible is also important, she explained.

The psychological trauma associated with amputation is another challenge facing the Cuban-led teams. Compounded by the language barrier and a general lack of health knowledge among patients, convincing them of the need to amputate has at times proven difficult, according to surgeons working at Hôpital Universitaire de la Paix, Port-au-Prince's main teaching hospital. "One older gentleman flat out refused to have his foot amputated. I explained gangrene and how he would eventually lose his leg, but he wouldn't do it," orthopedic surgical resident Douglas Valverde from Costa Rica told me as I accompanied him on rounds. "We had another patient, a 16-year old girl who was severely depressed-with good reason-after we amputated her leg. But that's not always the case," he says, motioning to a woman whose right leg has been amputated below the knee. "With most amputees, the main problem isn't with their missing limb, but rather with their mental state. Not with this patient. She has adapted well, and feels secure and attractive enough to want her picture taken." 
Still, identifying and enlisting patients needing prostheses hasn't been easy. Even at the Centre Hospitalier de la Renaissance, where rehabilitation services enjoy wide acceptance, the Cuban team had only eight eligible candidates by April 1.[8] Increasing that number is the aim of an outreach project being implemented by the doctors and nurses at primary health care posts in tent cities and hospitals in and around Port-au-Prince. Once patients are identified and fitted with their prostheses, they'll set out on a second round of rehabilitation, accompanied by therapists in the Cuban-led teams.

\section{Looking Ahead}

In 37 seconds of ground-wrenching terror, Haiti's cruel, widespread inequities were thrown into stark relief for global audiences, offering a glimpse of the schisms, poverty and neglect that predate this natural disaster. Like quake victims now undergoing rehabilitation, Haiti's ability to "walk again" or to "walk at all" depends on local and international commitment, stakeholders coming together to forge long-term, sustainable and equitable solutions.

According to a report prepared for the UN, World Bank and Haitian government, that commitment should materialize in a health system that is universal, decentralized, and guarantees quality services and access to essential medicines.[9] In short, it should be a system that aims to mitigate social determinants which prevent the majority of Haitians from attaining better health and well-being. Multilateral agreements among Haiti, Cuba, Venezuela, Brazil, Norway, Namibia, UN agencies, and NGOs with long-standing commitment to health care and equity in Haiti are providing the foundation for that universal health system by building, equipping and staffing health facilities throughout the country.

As over the past 12 years, Cuban cooperation contributes an essential element of sustainability to this new effort, committing trained human resources for public hospitals and clinicsincluding Cuban doctors, nurses, and rehabilitation specialists; and hundreds of graduates of the Latin American Medical School from the region and the world over. Perhaps most important of all is Cuba's training of over 800 young Haitian physicians at the School, over half of them already graduated, who represent the potential for lasting transformation in the health system and the health picture in their country. -1 -

This report is the result of Senior Editor Conner Gorry's monthlong assignment covering the Henry Reeve Contingent in and around Port-au-Prince. For more, see the next issue of MEDICC Review, with Part Il of the Once the Earth Stood Still series on rebuilding the Haitian health system and Field Notes from MEDICC: http://mediccglobal.wordpress.com.

\section{References \& Notes}

1. Cooperation includes free corrective eye surgery (Operación Milagro), scholarships for young Haitians to the Latin American Medical School (ELAM), and Cuban health professionals posted in Haiti, mainly among remote and vulnerable populations (Comprehensive Health Program). The latter also includes vaccination campaigns, health promotion and education, vector control and other population health components. Together, these programs have bolstered the Haitian public health system by posting between 300 and 400 Cuban health professionals in public hospitals and clinics for the last 12 years.

2. Brigada Médica Cubana en Haití. Boletín de Prensa No. 7. Brigada Medica Cubana en Haití. Port-au-Prince, Haiti. 18 Mar 2010.

3. The Henry Reeve Medical Contingent was founded in 2005 in response to Hurricane Katrina. For details see: Cuba's Response to Katrina Disaster. MEDICC Review. 2005 Aug-Sep;7(8):31-2. Available from: http://www.medicc.org/publications/medicc_review/0805/headlines-in-cuban-health.html. For the Contingent's work since its establishment, see Cuban Health Cooperation Turns 45. MEDICC Review. 2008 Summer;10(3):44-7. Available from: http://medicc.org/ mediccreview/index. php?issue $=3 \& i d=22 \& a=v a$.

4. Although the scale back was relatively measured throughout March, it accelerated as seasonal rains and the official date for the end of the emergency phase approached. Set for April 12, this meant that public hospitals and health clinics in Haiti would resume charging for services on this date. For more on doctors withdrawing, see Dugan IJ. Emergency Doctors Leave Haiti. WSJ. 2010. 23 Feb 2010. Available from: http://online.wsj.com/article/SB1000142405274870 3503804575083973597429774.html\#articleTabs_comments\%3D\%26articleT abs\%3Darticle.

5. Under the terms of the accord, Brazil pledged \$USD 80 million to help rebuild the Haitian health system and establish a national epidemiological surveillance network. For more see http://mediccglobal.wordpress.com/2010/03/30/trilateral-accord-signed-to-rebuild-haitian-public-health-system/.

6. ELAM doctors committing to a year or more were offered the opportunity to pursue their family medicine residency while serving in Haiti.

7. The number of rehabilitation clinics is slated to increase to 30 by year's end. Brigada Médica Cubana en Haití. Boletín de Prensa No. 9. Brigada Medica Cubana en Haití. Port-au-Prince, Haiti. 9 Apr 2010.

8. Factors complicating the identification of prostheses candidates include the perception that all health services (including those offered by the Cubans) are fee-based; transportation and mobility difficulties; and the lack of knowledge about prostheses and rehabilitation in general.

9. Jordan M. Facing dwindling medical health from abroad, officials plan postquake system, seek outside funds. WSJ. 2010. 19 Mar 2010. 